\title{
THE EVALUATION OF MULTIPLICATION CAPACITY IN GALLERIA OF ENTOMOPATHOGENIC NEMATODE ISOLATES FROM VIETNAM
}

\author{
NGUYEN NGOC CHAU, VU TU MY, NGUYEN THI DUYEN \\ Institute of Ecology and Biological Resources, VAST
}

RALF-UDO EHLERS

Christian Albrechts Universitat Kiel, Germany

\begin{abstract}
A total of 43 isolates of entomopathogenic nematodes of Vietnam were assessed on reproduction capacity in the last instar larvae of great wax moth (Galleria mellonella). The total yield of infective juveniles (IJs) on the Galleria mellonella were varied between indigenous isolates with significant different of multiplication. The amounts of IJs were produced in each Galleria from several thousands to hundreds thousands. These were shown a great difference of the reproduction capacity between indigenous isolates/species of entomopathogenic nematodes. In general, the multiplications of Steinernema isolates were lower than the multiplication of Heterorhabditis isolates. Among Steinernema isolates, however, the multiplications of some isolates were relatively low such as isolate S-DL9 (S. eapokense) with 4,378 \pm 509 IJs, whereas other ones were relatively high such as S-TX1 (S. sangi) with $68,343 \pm 8,942$ IJs. These were also occurred significant difference between isolates within species that were particularly happened isolates of Heterorhabditis indica with average yields varieties from $18,900 \mathrm{IJs}$ at H-PP16 to $233,500 \pm 39,100$ at H-NT3. The experiments showed the relationship between multiplication capacity of IJs and inoculation concentration and each isolate has an optimal inoculation concentration for highest multiplication. These data to be provided the important information for evaluation of potential isolates for biocontrol.
\end{abstract}

Keywords: Entomopathogenic nematodes, reproduction in G. mellonella, Steinernema, Heterorhabditis, Vietnam.

Entomopathogenic nematode species (EPN) of two genera Steinermatidae and Heterorhaditidae are obligated parasites in insects and they are usually infecting and killing a broad range of insect species. These characters of EPN have been used them as prospective biological control agents of insect pests in a variety of crops [3]. As naturally, each species/strains of EPN has usually linked with several their host insects whose relationships have been informed long time together with their local geographical-climate distributions. Therefore, the indigenous isolates/strains of nematodes have several merits to local insect pests.

The survey and sampling of indigenous EPN is not only provided information on EPN distribution but these is also supplied potential isolates/strains which might be more suitable for the inundation release against local insect pests because of adaptation to local climate and population regulators. Even the information on available of indigenous EPN is very useful for any decision prior to possible introduction of exotic species. Since benefit of the indigenous EPN, the survey and collection works on EPN have not only limited in the Europe, North America and Australia but have also been extended to Asian, African and Latin American countries. These leading to increasing number of EPN isolates/species [2]. The number of EPN surveys in tropical and subtropical regions has significantly increased during last decade.

The survey and isolation of entomopathogenic nematodes in Vietnam were started in 1997. Up to now, there are about fifty of entomopathogenic nematode isolates isolated and maintained by living cultures in the Laboratory. Most of entomopathogenic nematodes previously were unknown and their 
comprehensive studies based on morphological and molecular characterization as well as conducting some cross breeding tests allowed imaging a picture of the biodiversity of EPN in Vietnam [7, 9-12]. Concurrently with taxonomy works, the pathogenicity tests based on the indigenous isolates were obtained with Galleria mellonella and then with some insect pests to evaluate the potential of indigenous isolates for biological control. Recently, almost results of the pathogenicity tests on insect pests were published [4-6]. In the scope of experimental tests in the laboratory condition, the reproduction capacity of indigenous EPN isolates were assessed and evaluated. The pathogenicity and reproduction capacity are usually allowed the using potential isolates for biological control.

The present paper is given the assessment on reproduction capacity of indigenous isolates of entomopathogenic nematodes in Vietnam. Most of the studies were conducted in Vietnam during years 1999-2003 and some further examined experiments were carried out in the Laboratory of Biotechnology and Biocontrol, Kiel University, Germany in 2005 before their deposit in liquid nitrogen.

\section{MATERIAL AND METHOD}

A collection of living entomopathogenic nematodes which consists of 43 isolates belonging to 18 entomopathogenic species has been maintained in the Department of Nematology, Institute of Ecology and Biological Resources. All these isolates were used for the assessment of the multiplication potential on last instars larvae of great wax moth, G. mellonella. Apart from indigenous isolates some introduced isolates such as DL36 (Steinernema carpocapsae), S. arenaria, HP88 (Heterorhanditis bacteriophora) has been used for the competition.

For maintaining cultures of entomopathogenic nematodes: each isolate was periodically cultured depending their survival time in the storage temperature at $14^{\circ} \mathrm{C}$ that condition allowed survival of Steinernema isolates for approximately 180 days and that were app. 90 days for survival of Heterorhabditis isolates. Inoculation concentration was $100 \mathrm{IJs} /$ Galleria.
Testing procedure for estimation of best-fit concentration of EPN inoculation for highest EPN multiplication capacity: each EPN isolates was conducted with ten different concentrations of IJs that were between 10 and $100 \mathrm{IJs} /$ Galleria. Each concentration formula was used ten last instars larvae of G. mellonella for inoculation in a $9 \mathrm{~cm}$ diameter petri dish which is transferred $1 \mathrm{ml}$ of distilled water contained following concentration 100, 200, 300, 400, 500, 600, 700, $800,900,1000$ IJs on a Whatman filter paper then placed 10 Galleria for exploring for 48 hours in room temperature. All dead Galleria by EPN was determined and cadavers were transferred to another wetted Whatman paper putted into Petri dish for incubation during 4-10 days. Collection of IJs by water trap [14] and IJs were calculated with a counting dish under stereomicroscope. The multiplication experiment was repeated at least five times in the same condition. Average of IJs produced on each Galleria was statistically processed following Anon with correlation index $\left(\mathrm{R}^{2}\right)$ to estimate goodness-of-fit-test of optimal concentration for each EPN with highest multiplication.

\section{RESULT AND DISCUSSION}

\section{The reproduction capacity in Galleria of indigenous enthomopathogenic nematode isolates}

The reproduction character and its multiplication capacity of entomopathogenic nematode isolates can be considered as important category of a potential agent for biological control. The high multiplication capacity of any EPN isolate to be not only expressed a high sensitive of the insect host to EPN isolate, but it's allowed the culture of EPN with high production.

In our experiments when EPN isolates were periodically cultured for maintenance purpose, the total IJs yield of indigenous isolates produced per Galleria were significantly variable in a range between several thousands and hundreds thousands among different species of these indigenous entomopathogenic nematodes. In general, the total yields of Steinernema isolates and species were less than those of Heterorhabditis isolates. Among Steinernema isolates the yield of some isolates were relatively low such as S-DL9 (Steinernema sp.1), S-TS2 (S. 
sasonense), S-DL14 (S. cumgarense), S-DL23 (Steinernema sp.1) with 4,378 \pm 509 IJs, 5,000 \pm $600(3,800-5,700)$ IJs, $5,500 \pm 300(5,100-5,900)$ IJs, 5,700 $\pm 500(5,100-6,600)$ IJs, respectively. These yields however were relatively high at some isolates such as S-TX1, S-XS4 (Steinernema sangi), S-TK10 (Steinernema loci), S-TN10 (S. robustispiculum) and S-XT (Steinernema sp.6) with 68,343 $\pm 8,942(55,900$ $75,100)$ IJs, $36,600 \pm 2,200(34,300-39,600)$ IJs, $34,400 \pm 5,200(31,800-40,400)$ IJs, 32,000 \pm $1,100(30,500-33,100)$ IJs and 30,100 \pm 900 $(28,800-31,500)$ IJs, respectively.

The reproduction capacities were not only occurred with larger varieties between species and isolates among the genera and inside each genus but also occurred even very much different between isolates within the species. The difference was particularly found within isolates of Heterorhabditis indica species with average yields from $18,900 \pm 400(18,400-19,800) \quad \mathrm{IJs}$ at H-PP16 to $233,500 \pm 39,100(218,600-269,900)$ at H-NT3. In the Steinernema sangi species this broad variation was occurred between three isolates with the average yields from 7,000 \pm 500 $(6,300-7,700)$ IJs to $68,343 \pm 8,942(55,900-$ $75,100)$ IJs. In case of species $S$. robustispiculum with four experimented isolates the reproduction capacity was significantly varied from 18,600 \pm 1,600 to 22,500 IJs. Some other examples on the difference of reproduction capacity were occurred with the species of $S$. sasonense when their average multiplication yields were varied between 5,000 to 19,800 IJs per Galleria (table 1).

Table 1

Infective juvenile yields of $\mathbf{4 3}$ indigenous entomopathogenic nematode isolates of Vietnam

(in the laboratory conditions)

\begin{tabular}{|c|l|c|c|}
\hline $\mathbf{N}$ & \multicolumn{1}{|c|}{ Species } & Strains & IJs yield per Galleria $(\times 1000)$ \\
\hline 1. & H. indica & H-BB9 & $24.0 \pm 0.5(23.4-25.1)$ \\
\hline 2. & H. indica & H-CP16 & $127.2 \pm 7.0(124.4-128.1)$ \\
\hline 3. & H. indica & H-CP6 & $26.5 \pm 0.4(25.8-27.3)$ \\
\hline 4. & H. indica & H-CP8 & $27.3 \pm 0.8(26.4-28.5)$ \\
\hline 5. & H. indica & H-HS5 & $24.4 \pm 0.6(23.3-25.2)$ \\
\hline 6. & H. indica & H-MP11 & $180.8 \pm 3.2(178.0-184.4)$ \\
\hline 7. & H. indica & H-NT3 & $233.5 \pm 39.1(218.6-269.9)$ \\
\hline 8. & H. indica & H-PP16 & $18.9 \pm 0.4(18.4-19.8)$ \\
\hline 9. & H. indica & H-QB2 & $31.9 \pm 0.8(30.9-33.4)$ \\
\hline 10. & H. indica & H-QB3 & $32.1 \pm 0.6(31.5-33.6)$ \\
\hline 11. & H. indica & H-TN48 & $24.3 \pm 0.6(23.5-25.1)$ \\
\hline 12. & S. eapokense & S-DL16 & $7.8 \pm 0.9(6.4-8.8)$ \\
\hline 13. & S. eapokense & S-DL20 & $5.8 \pm 0.4(5.4-6.7)$ \\
\hline 14. & S. eapokense & S-DL21 & $6.1 \pm 0.5(5.3-6.8)$ \\
\hline 15. & S. eapokense & S-DL22 & $6.1 \pm 0.4(5.3-6.5)$ \\
\hline 16. & S. cumgarense & S-DL13 & $6.4 \pm 0.4(5.6-6.9)$ \\
\hline 17. & S. cumgarense & S-DL14 & $5.5 \pm 0.3(5.1-5.9)$ \\
\hline 18. & S. sangi & S-MP9 & $7.0 \pm 0.5(6.3-7.7)$ \\
\hline 19. & S. sangi & S-TX1 & $68.3 \pm 8.9(55.9-75.1)$ \\
\hline 20. & S. sangi & S-XS4 & $36.6 \pm 2.2(34.3-39.6)$ \\
\hline 21. & S. robustispiculum & S-TN10 & $32.0 \pm 1.1(30.5-33.1)$ \\
\hline 22. & S. robustispiculum & S-TN24 & $18.6 \pm 1.6(16.4-22.1)$ \\
\hline 23. & S. robustispiculum & S-TN21 & $23.2 \pm 1.9(20.3-25.7)$ \\
\hline 24. & S. robustispiculum & S-TN22 & $23.4 \pm 1.3(21.2-25.1)$ \\
\hline 25. & S. sasonense & S-TN53 & $19.8 \pm 0.7(18.7-21.2)$ \\
\hline 26. & S. sasonense & S-TS2 & $5.0 \pm 0.6(3.8-5.7)$ \\
\hline & & & \\
\hline & & \\
\hline
\end{tabular}




\begin{tabular}{|c|l|c|c|}
\hline 27. & S. sasonense & S-TS10 & $19.4 \pm 0.6(18.5-20.2)$ \\
\hline 28. & Steinernema loci & S-TK10 & $34.4 \pm 5.2(31.8-40.4)$ \\
\hline 29. & S. thanhi & S-TG10 & $24.7 \pm 0.4(23.9-25.2)$ \\
\hline 30. & Steinernema sp.B & S-TD16 & $7.5 \pm 0.4(6.9-8.3)$ \\
\hline 31. & Steinernema sp.B & S-TD6 & $8.9 \pm 0.7(7.5-10.2)$ \\
\hline 32. & Steinernema sp.C & S-BM12 & $22.5 \pm 0.6(21.3-23.3)$ \\
\hline 33. & Steinernema sp.E & S-TN9 & $31.5 \pm 1.1(30.2-33.0)$ \\
\hline 34. & Steinernema sp.E & S-TN38 & $22.3 \pm 0.7(21.2-23.6)$ \\
\hline 35. & Steinernema sp.J & S-CP13 & $28.4 \pm 1.5(25.4-30.2)$ \\
\hline 36. & Steinernema sp.J & S-CP14 & $27.3 \pm 1.7(24.3-30.1)$ \\
\hline 37. & Steinernema sp.1 & S-DL23 & $5.7 \pm 0.5(5.1-6.6)$ \\
\hline 38. & Steinernema sp.1 & S-DL9 & $4.4 \pm 0.5(3.6-5.3)$ \\
\hline 39. & Steinernema sp.2 & S-NH7 & $6.4 \pm 0.3(6.1-6.8)$ \\
\hline 40. & Steinernema sp.3 & S-BC & $6.2 \pm 0.5(5.3-6.7)$ \\
\hline 41. & Steinernema sp.4 & S-CP12 & $6.9 \pm 0.7(5.5-7.7)$ \\
\hline 42. & Steinernema sp.5 & S-HS2 & $9.2 \pm 0.6(8.3-10.2)$ \\
\hline 43. & Steinernema sp.6 & S-XT & $30.1 \pm 0.9(28.8-31.5)$ \\
\hline
\end{tabular}

The difference on reproduction capacity between entomopathogenic nematode isolates among species of the genus and within the isolates of each species might be depended on natural habitat and almost related with insect host in the nature. In the Laboratory condition, the multiplication experiment tests were carried out with the same insect host as great wax moth, Galleria mellonella so most of them might be not affected by natural insect hosts. Because the multiplication of each EPN isolates is as result of the complex interactions between parasitic nematodes and their symbiotic bacterium on each insect host, these interactions of nematode-bacterium lead to different reproduction and it can be interpreted of how different multiplication is between EPN isolates/species.

In comparison with some other introduced strains that were evaluated and screened as agents for biological control such as D-36 ( $S$. carpocapsae), S. arenaria and HP88 ( $H$. bacteriophora), in the same of culturing conditions, some indigenous isolates were shown the multiplication with an equivalent level or even somewhat higher yield such as $\mathrm{H}-$ NT3, H-MP11 and H-CP16 ( $H$. indica) with average yield from 233,500 IJs, 180,800 IJs and 127,200 IJs, respectively. In genus Steinernema, isolate S-XT (Steinernema sp.6), S-TN9 (Steinernema sp.E), S-TK10 (S. loci),
S-XS4, S-TX1 (S. sangi) were found with average yield from 30,140 IJs, 31,960 IJs, 34,370 IJs, 36,340 IJs and 68,340 IJs, respectively. The reproduction yields of Steinernema isolates of Vietnam were less than data on multiplication capacity of $S$. feltiae conducted by Dutky et al. [1] on Galleria with 200,000 IJs/Galleria. However, it was clearly that in most of Steinernema isolates/species which had been valued for biological control, the multiplication capacity varied between 30,000-50,000 IJs [13]. In other experiment on valuation of reproduction capacity of $H$. bacteriophora, the multiplication was yielded with 35,000 IJs [8]. Thus the multiplication of entomopathogenic nematodes inside insect host as Galleria might be depended on biological property of EPN strain and their intinial infective density. Apart from that, normally for any EPN strain with smaller size of body as almost strain of Heterorhabditis spp., their multiplication yields are trended as higher than multiplication yields of strains with larger size of body such as almost strains of Steinernema species.

Although these tests are conducted in the laboratory condition on standard insect host with Galleria as frequency, their data on reproduction are being valuable assessments on toxicological level concerning mass producing of specific strain of symbiosis bacterium. Consequently, based on these data of reproduction yields, some 
indigenous with moderate high multiplication has been evaluated as potential strains and their further assessments on their optimal reproduction and their pathogenicity on insect pests are need to be conducted.

\section{Relation between final yield and concentration of infested IJs}

In each EPN isolate, the highest reproduction yield was depending on inoculation concentration of infective juvenile of each tested isolates. In our assays carried out with four indigenous isolates, the highest yields of all isolates were obtained with inoculated concentration of IJs from 60-70 IJs of S-TK10 and S-TX1 (Steinernema spp.) per Galleria (table 2). The relation between yield and infested IJs in all assays showed clearly with a close correlation (fig. 1 and 2). This mean that each isolate is being with the highest yield or highest multiplication that corresponded with a certainly inoculated concentration of IJs that is usually considered as the best fit inoculated concentration for each EPN isolate.

Table 2

The relationship between yield and inoculated concentration of trains S-TK10 and S-TX1 (temp: $26.1-29.4^{\circ} \mathrm{C}$; humidity: $77-86 \%$ )

\begin{tabular}{|c|c|c|}
\hline \multirow{2}{*}{ Infested IJs } & \multicolumn{2}{|c|}{ Number IJ per Galeria $(\times 1000)$} \\
\cline { 2 - 3 } & Steinernema loci $($ TK10) & Steinernema sangi $($ TX1) \\
\hline 10 & $12.1 \pm 4.0(8.1-16.1)$ & $35.7 \pm 13.9(27.1-51.7)$ \\
\hline 20 & $18.5 \pm 3.5(15.0-22.0)$ & $37.1 \pm 13.5(21.4-44.5)$ \\
\hline 30 & $19.6 \pm 2.8(16.8-22.5)$ & $33.4 \pm 6.4(29.5-40.8)$ \\
\hline 40 & $23.8 \pm 13.8(14.8-39.7)$ & $50.1 \pm 4.0(45.5-52.9)$ \\
\hline 50 & $26.9 \pm 1.6(25.9-28.8)$ & $55.7 \pm 7.5(49.3-64.0)$ \\
\hline 60 & $27.8 \pm 7.9(22.7-37.0)$ & $55.8 \pm 12.9(41.5-66.6)$ \\
\hline 70 & $34.4 \pm 5.2(31.8-40.4)$ & $54.5 \pm 7.6(45.9-60.3)$ \\
\hline 80 & $23.9 \pm 4.4(19.8-28.5)$ & $49.9 \pm 6.0(44.4-56.3)$ \\
\hline 90 & $29.6 \pm 5.6(23.6-34.9)$ & $47.1 \pm 9.8(37.6-57.2)$ \\
\hline 100 & $22.7 \pm 6.5(15.7-28.4)$ & $53.8 \pm 10.0(45.3-64.8)$ \\
\hline
\end{tabular}

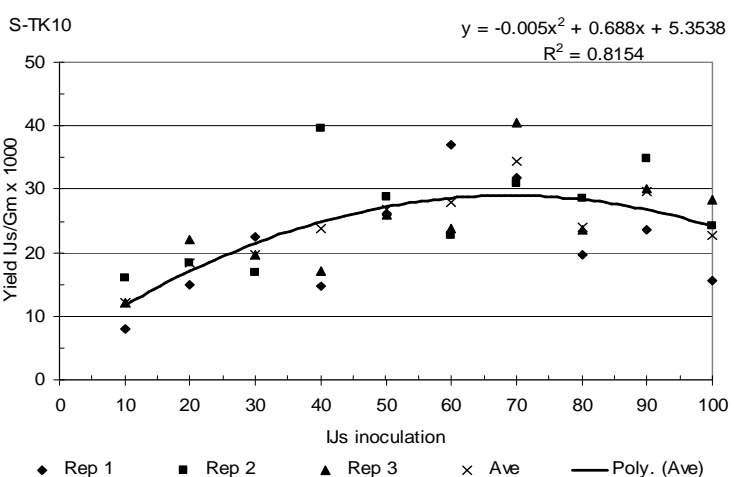

A

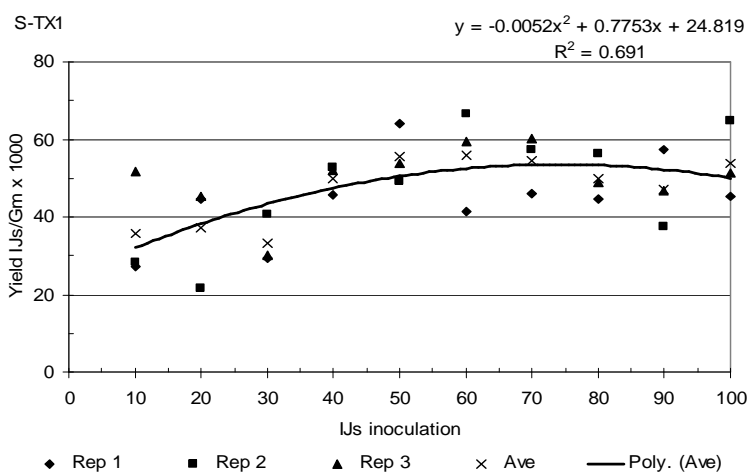

B

Figure 1. Correlation between IJs yields and concentration of infested IJs

A. S-TK10 (Steinernema loci); B. S-TX1 (Steinernema sangi).

This similarity is also occurred with two strains of the species Heterorhabditis indica when the optimal of the inoculated concentration of IJs was 50 IJs at H-MP11 and 60 IJs at H-NT3 per Galleria (table 3). The yield curves may be in both cases were moderate regulation and the correlation value was also tight in H-MP11 but in case of H-NT3 it dropped points of production yields which were not too much close to the curve.

It is evidently that in the same culture condition but there was some difference 
appeared about multiplication yield of the same isolate. This might be interpreted on the dependant of inoculation concentration of each isolate.

Table 3

The relationship between yield and inoculated concentration of trains H-MP11 and H-NT3 (temp: $26.1-29.4^{\circ} \mathrm{C}$; humidity: $77-86 \%$ )

\begin{tabular}{|c|c|c|}
\hline \multirow{2}{*}{ Infested IJs } & \multicolumn{2}{|c|}{ Number IJ per Galleria $(\times 1000)$} \\
\cline { 2 - 3 } & Heterorhabditis indica (MP11) & Heterorhabditis indica $(\mathbf{N T 3 )}$ \\
\hline 10 & $140.3 \pm 6.2(134.2-146.6)$ & $137.4 \pm 33.1(101.7-167.0)$ \\
\hline 20 & $150.4 \pm 10.8(142.6-162.7)$ & $139.4 \pm 15.9(122.0-153.2)$ \\
\hline 30 & $162.5 \pm 7.8(153.9-169.0)$ & $151.5 \pm 20.4(130.5-171.2)$ \\
\hline 40 & $166.4 \pm 13.1(151.4-174.3)$ & $176.1 \pm 15.9(162.0-193.3)$ \\
\hline 50 & $180.8 \pm 3.2(178.0-184.4)$ & $229.7 \pm 28.1(204.0-259.7)$ \\
\hline 60 & $171.6 \pm 6.3(164.4-176.3)$ & $233.5 \pm 39.1(238.6-269.9)$ \\
\hline 70 & $162.6 \pm 7.4(154.4-168.9)$ & $167.1 \pm 19.1(149.6-187.6)$ \\
\hline 80 & $161.9 \pm 6.9(156.6-169.7)$ & $141.3 \pm 14.3(129.7-157.3)$ \\
\hline 90 & $152.4 \pm 10.5(141.2-162.1)$ & $139.1 \pm 13.7(128.0-154.4)$ \\
\hline 100 & $147.4 \pm 8.7(141.2-157.3)$ & $130.4 \pm 15.5(112.9-142.4)$ \\
\hline
\end{tabular}

The difference on value of the standard deviation between isolates was indicated the stable level of multiplication yield for each EPN isolate. The high value of standard deviation implies that the multiplication yield of any isolate is less stable than those of low value of standard deviation. This also mean that most of isolates with low multiplication yield and high value of standard deviation were less stable whereas isolates with high multiplication yield and low value of standard deviation were usually more stable. In addition, some isolates with low multiplication yield is usually difficult for culturing and maintaining. This interpreted that the EPN isolate might be not too much compatible with the insect host as Galleria other than its natural host.
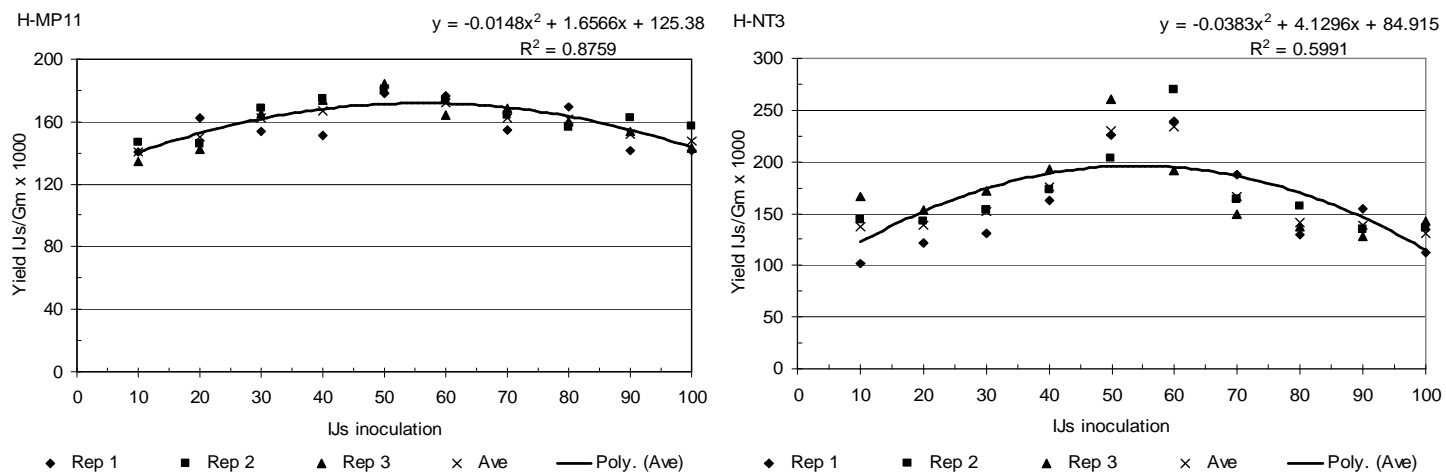

Figure 2. Correlation between IJs yields and concentration of infested IJs A. H-MP11; B. H-NT3 (Heterorhabditis indica).

Acknowledgements: The senior author is grateful to the DAAD for a scientist exchange grant, which enabled him to conduct a research visit to the Laboratory of Biotechnology and Biocontrol, Universitat Kiel, Germany. The financial support for the survey and sampling on entomopathogenic nematodes in Vietnam granted by the Vietnam National Program for Basic Research in Natural Sciences is also gratefully acknowledged. 


\section{REFERENCES}

1. Dutky et al., 1964: J. Insect Pathol., 6: 417422.

2. Hominick W. M., 2002: Biogeography. In: R. Gauger (ed.), Entomopathogenic Nematology. CABI Publishing, Oxon, UK: 115-143.

3. Kaya H. K. \& R. Gaugler, 1993: Annu. Rev. Entomol, 38: 181-206.

4. Lai P. H., Moens M. \& Nguyen N. C., 2003: Tạp chí Khoa học, 1: 105-109.

5. Lai P. H., Moens M. \& Nguyen N. C., 2003: Tạp chí Khoa học, 1: 127-131.

6. Lại Phú Hoàng, Nguyễn Ngọc Châu, 2003: Những vấn đề nghiên cứu cơ bản trong khoa học sự sống, Nxb. Khoa học và Kỹ thuật, Hà Nội.
7. Pham V. L. et al., 2000: Russian Journal of Nematology, 8: 33-43.

8. Milstead \& Poinar, 1978: Calif. Agric., 32(3): $12 \mathrm{pp}$.

9. Phan K. L., Nguyen N. C. \& Moens M., 2001a: Russian Journal of Nematology, 9: 1-7.

10. Phan K. L., Nguyen N. C. \& Moens M., 2001b: Nematology, 3: 503-514.

11. Phan K. L. et al., 2003: Nematology, 5: 367382.

12. Phan K. L. et al., 2005: Systematic Parasitology, 60: 23-32.

13. Poinar, 1979: Nematodes for biological control of insects. CRC Press: 277 pp.

14. White, 1927: A method for obtaining infective nematode larvae from cultures. Science, 66: 302-303.

\title{
ĐÁNH GIÁ KHẢ NĂNG SINH SẢN TRÊN GALLERIA CỦA CÁC CHỦNG TUYẾN TRÙNG KÝ SINH GÂY BÊNH CÔN TRÙNG Ở VIÊT NAM
}

\author{
NGUYỄN NGOC CHÂU, VŨ TỨ MỸ, \\ NGUYỄN THI DUYÊN, RALF-UDO EHLERS
}

\section{TÓM TÁ́T}

Tổng số 43 chủng tuyến trùng ký sinh gây bệnh côn trùng bản địa Việt Nam đã được đánh giá khả năng sinh sản trong ấu trùng bướm sáp lớn (Galleria mellonella). Sản lượng thu hoạch của ấu trùng cảm nhiễm (IJs) trên Galleria thay đổi giữa các chủng tuyến trùng với sự khác biệt về sinh sản lớn. Số lượng ấu trùng cảm nhiễm được sinh ra trong mỗi Galleria từ một vài ngàn đến hàng trăm ngàn. Điều này chứng tỏ có sự khác nhau lớn về khả năng sinh sản giữa các chủng/các loài tuyến trùng ký sinh gây bệnh côn trùng. Nhìn chung, sự sinh sản của các chủng Steinernema thấp hơn so với các chủng Heterorhabditis. Trong số các chủng Steinernema thì một số chủng có sản lượng IIs tương đối thấp như S-DL9 (thuộc loài S. eapokense) với sản lượng IIs trung bình chỉ đạt $4.378 \pm 509$ IJs, trong khi đó một số chủng có sản lượng IIs tương đối cao như STX1 (loài $S$. sangi) với sản lượng IIs trung bình đạt $68.343 \pm 8.942$ IJs. Sự khác nhau này cũng xảy ra đối với các chủng EPN trong cùng loài, đặc biệt ở các chủng của loài Heterorhabditis indica với sản lượng IIs trung bình thay đổi từ 18.900 IJs ở chủng H-PP16 đến $233.500 \pm 39.100$ ở chủng H-NT3. Các thí nghiệm cho thấy có mối tương quan chăt chẽ giữa nồng đô gây nhiễm và khả năng sinh sản của các chủng tuyến trùng, trong đó mỗi chủng tuyến trùng có một sản lượng IJs cao nhất ứng với một nồng độ gây nhiễm tối ưu. Số liệu về khả năng sinh sản của các chủng EPN cung cấp thông tin quan trọng cho việc đánh giá và tuyển chọn các chủng tuyến trùng tiềm năng cho phòng trừ sinh học sâu hại. 